\title{
Amazon Forest Maintenance as a Source of Environmental Services
}

\author{
PHILIP M. FEARNSIDE
}

\author{
Instituto Nacional de Pesquisas da Amazônia (INPA), Caixa Postal 478, 69011-970 Manaus, AM, Brasil \\ Manuscript received on October 8, 2007; accepted for publication on January 21, 2008; \\ contributed by PHILIP M. FEARNSIDE*
}

\begin{abstract}
Amazonian forest produces environmental services such as maintenance of biodiversity, water cycling and carbon stocks. These services have a much greater value to human society than do the timber, beef and other products that are obtained by destroying the forest. Yet institutional mechanisms are still lacking to transform the value of the standing forest into the foundation of an economy based on maintaining rather than destroying this ecosystem. Forest management for commodities such as timber and non-timber forest products faces severe limitations and inherent contradictions unless income is supplemented based on environmental services. Amazon forest is threatened by deforestation, logging, forest fires and climate change. Measures to avoid deforestation include repression through command and control, creation of protected areas, and reformulation of infrastructure decisions and development policies. An economy primarily based on the value of environmental services is essential for long-term maintenance of the forest. Much progress has been made in the decades since I first proposed such a transition, but many issues also remain unresolved. These include theoretical issues regarding accounting procedures, improved quantification of the services and of the benefits of different policy options, and effective uses of the funds generated in ways that maintain both the forest and the human population.
\end{abstract}

Key words: Amazonia, avoided deforestation, Brazil, carbon, deforestation, global warming, Greenhouse effect, rainforest.

\section{INTRODUCTION}

\section{AMAZONIA's PRESENT ECONOMY}

The present economy of Brazilian Amazonia is almost entirely based on destroying the forest, either through predatory logging or deforestation for cattle pasture and, in some parts of the region, for soybeans. Sustainable activities such as rubber tapping and Brazilnut harvesting exist, but their relative importance is minimal from the standpoint of financial flows in today's economy. In addition, the rate at which these uses can produce products sustainably is limited and often compares unfavorably with predatory uses, unless, that is, the value of environmental services can be incorporated into the income stream.

\footnotetext{
* Member Academia Brasileira de Ciências Correspondence to: Philip Martin Fearnside E-mail: pmfearn@inpa.gov.br
}

\section{BARRIERS TO FOREST MANAGEMENT For CONVENTIONAL COMMODities}

\section{Timber}

Forest management for timber faces the contradiction between the slow growth rates of tropical-forest trees and the financial logic of investors who, whether explicitly calculated or not, act on the basis of commercial discount rates that reflect the returns that can be obtained on competing investments elsewhere in the economy (e.g., Fearnside 1979). Forest-management proponents tend to promise anything when a proposal is evaluated and licensed, but decades later when the first cycle of harvesting is complete the inherent contradictions must be faced and resolved if management is to continue in a sustainable way (Fearnside 2003a). In the first harvest cycle, large trees are being cut that have grown "for 
free" over centuries prior to the initiation of management. This is inherently more profitable than subsequent cycles when harvesting approaches an equilibrium after which the manager only harvests what has grown while the sustainable management operation has been waiting and investing in the trees. This transition represents a discontinuity with a risk of the land owner or manager abandoning the management plan in favor of either a predatory harvest or outright deforestation.

Forest management has additional impediments to sustainability when the managers are small or medium in size - a problem for which both environmental and social implications are negative. A large firm can, if it chooses, foresee the end of a resource it is exploiting unsustainably and prepare a transition to some other resource. A few of the major oil companies, for example, are beginning to reposition themselves as energy suppliers in a general sense and are looking for ways to shift their investments to sources other than oil. By contrast, Amazonian sawmill owners (who are usually relatively small-scale Brazilian entrepreneurs, not large multinational corporations) are not likely to switch to something else before the resource they are exploiting comes to an end. In fact, many have passed through a sequence of moves, destroying the forest resource first in the Atlantic-forest states of Espirito Santo or Paraná, then Amazonian forest in northern Mato Grosso and now in either southern Pará or in Rondônia. Within these Amazonian states, logging operations have often made a succession of moves from one frontier to the next. This gives reason to doubt the expectation that these sawmill operators will become converted to sustainable forest management, taking only the relatively modest harvests that can be cut without jeopardizing the system's sustainability.

\section{Non-timber forest products}

In the case of non-timber forest products (NTFPs), such as rubber and Brazil nuts, problems include inherent disadvantages of extractive systems as compared to plantations and the limits imposed by market saturation for many products if exploitation were scaled up to the areas available for management in Amazonia. Additionally, more prosaic temptations are ever present to increase the intensity of harvesting beyond sustainable limits, to increase the population beyond what can be supported by the resources at hand, and to increase areas of clearing for agriculture and pasture within the extractive areas, obviously at the expense of forest.

\section{Proposal For EnVIRONMENTAL SERViCES}

This author first proposed environmental services in 1985 as an adjunct to otherwise-unattractive plans for managing forest for timber (Fearnside 1985, 1989a) and nontimber forest products (Fearnside 1989b). Environmental services were grouped into three categories: biodiversity (Fearnside 1999a), water (Fearnside 2004), and avoiding global warming (Fearnside 1997a, 2000a, b). The hallmark of the proposal was its aim of tapping willingness to pay, as opposed to valuation of replacement costs or other indicators that serve as general illustrations of the fact that human societies depend on natural ecosystems. One should note the difference with the concept of "ecosystem services" (Costanza et al. 1997, 1998, Mooney and Ehrlich 1997, Pimentel et al. 1997, Daily et al. 2000), which was widely discussed at about the same time. The original ecosystem-services concept was a heuristic device, for example calculating a global total value of ecosystem services including polination by insects and provision of scenic beauty at US\$33 trillion, but no intention of such a sum ever being collected by service providers (Costanza et al. 1997). Discussion of ecosystem services has since evolved to focus on "payments for ecosystem services" (also "Payments for Environmental Services") (PES) programs where governments (usually local or national) pay landholders a stipend for such services as watershed maintenance. A wide variety of studies and conservation projects have derived from this. Most PES programs, such as those in Costa Rica and Mexico, reward watershed functions, but some also include carbon (Grieg-Gran et al. 2005, Karaousakis 2007).

During the Eco-92 or "Earth Summit" in Rio de Janeiro in 1992 my proposal for monetary flows based on environmental services evolved into a broader plan to shift the basis of the economy that supports Amazonia's rural population, replacing the current destructive pattern (Fearnside 1997b). International negotiations have progressed the farthest in the case of compensating the forest's role in avoiding global warming, but the other services are no less important. In fact, it is the co-benefits of maintaining biodiversity and water, in addition to indigenous peoples and other traditional human 
inhabitants of the forest, which most clearly sets Amazonian conservation apart from other greenhouse mitigation options such as planting Eucalyptus (e.g., Fearnside 1999b). Geopolitical concerns resulted in the avoidance of tropical deforestation being excluded from receiving carbon credit in the period through 2012, but important parts of these concerns do not apply to negotiations currently underway for the period from 2013 onwards, making inclusion of this environmental service likely (Fearnside 2001a, 2006a).

\section{Avoiding Global Warming AS AN ENVIRONMENTAL SERVICE}

Half of the dry weight of the trees is carbon, and this, together with part of the carbon in the soil under the forest, is released as carbon dioxide $\left(\mathrm{CO}_{2}\right)$ or as methane $\left(\mathrm{CH}_{4}\right)$ when the forest is cleared. Only a relatively small amount is recaptured by the pasture and secondary forests that subsequently occupy the landscape. Amazonia as a whole, including all countries and forest carbon stocks (not only above-ground live biomass, but also the roots, dead trees and soil stocks) has around $100 \mathrm{Gt}$ (gigatons = billion tons) of carbon that could be released (e.g., Fearnside 2000a). If this enters the atmosphere it would result in a very substantial increase in atmospheric $\mathrm{CO}_{2}$ concentration and global temperatures. Since many global climate models do not include this emission, these increases would be in addition to the already catastrophic increases indicated by the models as a result of fossilfuel emissions under the A2 (= business-as-usual) scenario of the Intergovernmental Panel on Climate Change (IPCC). This is the multi-model average of $4^{\circ} \mathrm{C}$ increase by 2100 over pre-industrial temperatures indicated by the IPCC's Fourth Assessment Report (IPCC 2007). It should also be noted that global mean temperature is dominated by temperatures over the oceans that occupy most of the Earth's surface, and average temperatures over the continents would be about $30 \%$ higher than the global mean. In the case of Amazonia the possibility of a "permanent El Niño" being established could mean even higher temperatures (Cox et al. 2004). In addition, the model runs used to generate the IPCC estimates (i.e., $4^{\circ} \mathrm{C}$ mean global increase by 2100 ) do not include warming from the emissions released by biosphere feedbacks, especially the large release of carbon that would occur if the Amazon forest succumbs to climate change. If included, biosphere feedbacks increase the predicted temperature in 2100 by $38 \%$ (Cox et al. 2004, p. 138).

If the possibility is taken into account of the global climate reacting to increased atmospheric $\mathrm{CO}_{2}$ more sharply than the increase corresponding to a $50 \%$ probability (i.e., under "high climate sensitivity," or a degree of security corresponding to a $95 \%$ probability), then the temperature could shoot up to much higher levels in Amazonia (e.g., Stainforth et al. 2005). The precautionary principle would indicate that these higher potential temperature increases should be considered in policy making, underscoring the importance of immediate actions to reduce global emissions of greenhouse gases, including those from Amazonian deforestation. A recent reanalysis of climatic sensitivity based on paleoclimatic evidence revised the estimate of "high climate sensitivity," or the point where there is $95 \%$ certainty that the true climate sensitivity is included, reducing it from 9.7 to $6.2^{\circ} \mathrm{C}$ (Hegerl et al. 2006).

Amazonia's stock of carbon could enter the atmosphere in two ways:

1) emissions from deliberate destruction of the forest by deforestation and by degradation through logging, and

2) emissions that are not made deliberately, as where forest is degraded due to climate change and by forest fires.

In the case of deliberate emission through deforestation, protected areas can have both short- and long-term effects. On the short term, creation of a reserve can cause a dramatic reduction in clearing by grileiros (large illegal claimants who occupy public land and obtain titles through fraud and corruption). The existence of a reserve greatly reduces the chance of grileiros or other invaders eventually gaining legal title, and therefore reduces the motive for clearing. Some of this activity can simply move to other locations (an effect known as "leakage" in the carbon literature), but some of the reduction is a net gain. Reserves have a measurable effect in decreasing deforestation (Ferreira et al. 2005, Nepstad et al. 2006). In addition, the placement of reserves can act as a barrier inhibiting the advance of deforestation into areas beyond the reserve itself (Fearnside 2003a). 
Degradation from climate change and fire can affect the entire forest, including that within protected areas. In addition to their role in slowing global warming by avoiding carbon emissions, reserves contribute to reducing degradation by maintaining the water-cycling functions of the forest. Because much of the rainfall in Amazonia is water that has been recycled through the forest, especially in the critically important dry season, keeping substantial blocks of forest in reserves maintains the climatic conditions needed to maintain forest in the remainder of the region (D'Almeida et al. 2007, Foley et al. 2007, Sampaio et al. 2007). Predominant winds in Amazonia blow from east to west, meaning that forests lying to the west of reserves are the ones that benefit from the evapotranspiration of the trees in the reserve. Reserves in eastern Amazonia would have the greatest benefit for maintaining rainfall within the Amazon region, while reserves in western Amazonia would have the most direct benefit in maintaining water-vapor transport to São Paulo and other parts of south-central Brazil (Fearnside 2004).

\section{THREATS TO AMAZONIAN FOREST}

\section{DEFORESTATION}

Amazonia's forests face serious threats, and the tendency is for many of them to increase in the future (Fearnside 2005a). Direct deforestation, by felling the forest with chainsaws, is the predominant cause of forest loss today. The great majority of deforested land becomes cattle pasture, either directly following clearing or after a brief period of agricultural use for annual crops. Pasture has been estimated to occupy $80 \%$ of the area deforested by 1995 (Barreto et al. 2005). Soybeans represent a recent addition to the forces driving deforestation. Soybeans are concentrated in certain locations in Amazonia, but they have a much more far-reaching effect on deforestation by providing the economic justification for major highway projects (Fearnside 2001b, 2002a, 2007). Roads are the primary force inducing the spread of deforestation (Laurance et al. 2001a, Nepstad et al. 2001, SoaresFilho et al. 2004, 2006). The continued expansion and improvement of the road network, together with the inflows of population and investment that the roads attract, point to continued increase in deforestation pressure in the coming years. This long-term trend is more funda- mental than some of the forces that can cause fluctuations in the annual rate of deforestation, such as repression campaigns and price oscillations of beef and soybeans and of the exchange rate of the Brazilian real against the US dollar. These short-term influences are relevant to the dip in Amazonian deforestation rate in 2005, 2006 and 2007, as well as to a ressurgence in Mato Grosso in 2007 when commodity prices began to recover (Souza Jr. et al. 2007). The trend since 1991 has been one of steady increase, as would be expected from the increases in underlying factors such as roads, population and investment (Laurance et al. 2001b, Fearnside 2005a).

Deforestation takes place in the context of a diverse array of actors, with great differences between locations in terms of who is responsible. Cattle ranchers are the greatest force. In addition to ranching for the "legitimate" economy - producing beef for sale - there is also a significant parallel economy. Money can be made from land speculation, where land is obtained cheaply and later sold for a much higher price, especially if legal title can be obtained and/or if a highway is built nearby (Fearnside 1987, Hecht et al. 1988). Deforestation of at least part of the land claim is the primary means of maintaining possession of the area and defending the investment against either invasion by squatters or expropriation by the government. Clearing also takes place as a use for money that is "laundered" when the funds are derived from illegal sources such as drug trafficking, government corruption, sale of stolen property and tax evasion. If money has come from an illegitimate source, the normal financial assumptions will not apply to the visible portion of the economy and more money may be spent than is returned in the form of beef sales. The proceeds, however, will be "clean" money that can be used in the open economy.

Forest is also lost due to flooding from hydroelectric dams. This land use is planned to occupy vast areas, ultimately totaling as much as 10 million hectares (Brazil, ELETROBRAS 1987, see Fearnside 1995a). This corresponds to $2 \%$ of Brazil's 5 million $\mathrm{km}^{2}$ Legal Amazon region, or $3 \%$ of the originally forested portion of the region. In addition to directly flooding forest, hydroelectric projects have much wider impacts in stimulating road building, migration and deforestation (Fearnside 1989c, 1999c, 2001c, 2005b, 2006b). 


\section{LOGGING AND FOREST FIRES}

Forest degradation through logging is a major factor in forest loss because of its interactions with other processes. Logging is often a prelude to deforestation, facilitating clearing by providing access on logging roads and by providing money to landholders through the sale of timber (Asner et al. 2005, 2006). Logging also greatly increases the probability of forest fires (Uhl and Buschbacher 1985, Alencar et al. 2004, 2006). These initiate a vicious cycle where fire kills trees by burning the bark at the base of each trunk (Barbosa and Fearnside 1999, Barlow et al. 2002). Next fire will be hotter and more destructive than the first one (Nepstad et al. 1999, 2001). After about three passages of fire the forest is destroyed and will appear as deforested on satellite images (Cochrane et al. 1999, Cochrane 2003).

\section{Climate Change}

Climate change is an increasing threat to Amazonian forest and some climate models (such as the Hadley Center model of the UK Meteorological Office) indicate a threat to the entire forest within the current century if global warming continues unabated (e.g., Cox et al. 2004). Even an average of the results of 15 different models, including those with less extreme outputs than the Hadley Center model, indicates the eastern portion of Amazonia being transformed from forest to savanna as a result of climate change (Salazar et al. 2007). Several factors are not included in the models that would greatly increase the damage, especially direct deforestation, logging and forest fires.

\section{MEASURES TO AVOID DEFORESTATION}

Measures to avoid deforestation, also called "reduction of deforestation and degradation" (REDD), can be grouped into the following categories:

\section{REPRESSION BY COMMAND AND CONTROL}

The main focus of government action to date has been on repressing deforestation through inspection and fines. Deforestation licensing combined with repression of unlicensed clearing was sucessful in reducing deforestation rates in Mato Grosso over the 1999-2001 period, providing a valuable demonstration of the capacity of government regulation to influence deforestation rates (Fearnside 2003b, Fearnside and Barbosa 2003).

\section{Protected AREAS}

Protected areas are an essential part of strategies to contain deforestation and the consequent release of carbon. In Brazilian Amazonia the demarcation of indigenous areas is particularly important because of the large area they cover and because of the role played by the indigenous peoples in actively defending their land from deforestation.

\section{INFRASTRUCTURE DECISIONS}

The history of highways in Amazonia shows a clear pattern of rapid clearing whenever a road is built or improved. Infrastructure decisions have a great influence on future deforestation, not only from the highway itself but also from migration of population and capital to new areas beyond the roads (Fearnside and Graça 2006, Fearnside 2007). This is a key part of the process that is not yet understood by many: it is not enough to create reserves and repress unauthorized clearing if new highways continue to proliferate.

\section{DEVElopment Policies}

Government development policies that affect deforestation include incentives for pasture and sawmills. Even today, the corporations that own ranches financed in the 1970s by the Superintendency for Development of Amazonia (SUDAM) can escape taxes on income earned outside of Amazonia by investing in their Amazonian properties (Brazil, MF, Secretaria da Receita Federal 2007, p. 341).

A long-standing policy issue is the land-tenure regulation that bases the granting of title to untitled (public) lands on showing that the claimant has made a "benfeitoria" (literally an "improvement," which basically means deforestation). The result is a built-in motive to clear regardless of what prohibitions or punishments may be enacted. Although many years have passed since this problem was raised (Fearnside 1979), it is still a fundamental driver of deforestation in the region. Another policy matter is agricultural financing, as government-subsidized credit is a major force behind expansion of both crops such as soybeans and more modest small-farmer agriculture. 
On the side of slowing deforestation, a variety of policy measures that are largely ineffective are often presented as deforestation countermeasures. For example, environmental education, while a worthwhile activity, is unlikely to be convince those who are actually cutting the forest. Another measure frequently invoked is agroforestry, but this land use is restrained from occupying very large areas by a variety of economic and physical limitations, and its role in discouraging forest clearing is limited (Fearnside 1995b). Agroforestry has a role in directly sequestering carbon (Tipper and De Jong 1998, De Jong et al. 2004). This land use also has an important potential role in Amazonia in providing a more sustainable form of agricultural production to small farmers (Smith et al. 1998).

The role of urbanization in reducing is controversial. Wright and Muller-Landau (2006) have suggested that this trend could significantly slow deforestation, but this has been strongly contested (Laurance 2006, Sloan 2007). The Manaus Free Trade Zone (SUFRAMA), which receives federal fiscal incentives as a policy decision to develop Amazonia, is claimed by the Amazonas state government as an effective break on deforestation due to the city's attraction of rural population.

Certification of various production activities has been proposed as a mitigation measure, but the results have been mixed. An example of the problem is provided by the 2006 loan from the International Finance Corporation (IFC), of the World Bank group, to a large slaughterhouse in Marabá, Pará (Folha de São Paulo 2007). In this case a certified activity can lead to more rather than less deforestation because the profitability of additional deforestation on many unregulated ranches in the surrounding area will also increase due to the presence of the slaughterhouse, leading to more deforestation. Nevertheless, certification initiatives for soybeans, beef and timber all have potential benefits in bringing these sectors into compliance with environmental laws and in minimizing their impacts (e.g., Zarin et al. 2004).

Agricultural intensification has been promoted as a means of avoiding deforestation (Sánchez et al. 1982). However, a variety of effects prevent this from assuming the desired role of slowing the loss of natural forest (Fearnside 1990). A similar intensification of ranching (Batjes and Sombroek 1997) also faces resource limits (Fearnside and Barbosa 1998).

\section{ENVIRONMENTAL SERVICES AS DEVELOPMENT}

\author{
DiRECT PAYMENTS For ENVIRONMENTAL \\ SERVICES (PES)
}

Direct payments for environmental services can sometimes be more effective in achieving environmental goals than are indirect programs to promote sustainable development, for example in the buffer zones around protected areas (Ferraro and Kiss 2002). Payment for environmental services (PES) programs in Costa Rica and Mexico are the ones with the most practical experience out of many such programs that have recently been initiated in tropical countries (Karaousakis 2006, 2007). Such programs are often criticized for paying the rich landholders instead of using government funds for more socially desirable ends that would reduce the inequalities in wealth distribution (Zbinden and Lee 2005, Grieg-Gran et al. 2005). In addition, the programs are often paying ranchers and other actors who have been destroying the forest, while traditional forest peoples who have much less impact are left with no reward for the environmental services of the forest.

The Proambiente program is designed to compensate the environmental services of small farmers who adopt agroforestry systems and maintain the carbon stocks in their properties (Mattos et al. 2001, Brazil, MMA 2003). The program depends on the budget of the Ministry of the Environment and has frequently not had funds available to pay the farmers as promised, therefore leading to a loss of credibility with local populations in the 13 pilot sites in Amazonia. Another PES program began in September 2007 in the state of Amazonas. In this program the state government pays a "forest stipend" (bolsa floresta) to small farmers and extractivists in stateowned land in exchange for a signed commitment to refrain from deforestation (Viana and Campos 2007). The program also has a component to compensate these farmers for ceasing to sell manioc flour as a commercial crop; the Amazonas state secretariat of the environment and sustainable development (SDS) expects the corresponding supply of demand for manioc flour in Manaus to be supplied from input-intensive farms outside of Amazonia, especially in Paraná. It should be noted, however, that the Amazonas state secretariat of rural production (SEPROR) hopes to increase manioc pro- 
duction by farmers in the state to make Amazonas selfsufficient in this dietary staple.

\section{VALUing EnVironmental SeRVices}

\section{Time and the value of forest}

What choices are made in allocating effort for conservation are heavily dependent on how the accounting for environmental services is done. In the case of the globalwarming mitigation, the value attributed to the deforestation that is averted by an action such as creation of a forest reserve is heavily dependent on decisions regarding the value of time. Time can be given value in various ways in carbon calculations: by applying to carbon either a discount rate or some alternative time-preference formulation, by setting a time horizon for the calculation, or both. I have argued that the value attributed to reserve creation will depend on whether the reserves are created near the deforestation frontier, where reserves that can be created are smaller and their cost higher but their benefit is almost immediate. If reserves are created far from the frontier, they are large and inexpensive but their carbon benefit will only occur at a future date when the deforestation frontier reaches the area. Tradeoffs therefore exist between reserve proposals in different locations (Fearnside and Ferraz 1995). Tradeoffs also exist between reserve creation and other types of mitigation measures, including avoided deforestation through command-andcontrol operations, tree planting and reduction of fossilfuel emissions.

A quantitative example is given in Fearnside et al. (2000, p. 262-264) comparing the carbon benefits of reserve creation with those of slowing the overall deforestation rate, as through enforcement of deforestation regulations with inspection and fines. The discount rate is the critical factor in determining which strategy is most beneficial in combating global warming. At a discount rate of $1 \% /$ year, a $50 \%$ reduction in deforestation has the same value as converting 5\% of the forest area into a protected area, whereas one would have to convert $22 \%$ to a protected area to have this effect if the discount rate were $5 \% /$ year. The long-term nature of carbon-stock protection afforded by protected areas gives them a strong advantage when the long term is given priority. Reserves have permanence that command-and-control restraints on deforestation lack, giving them additional value in avoiding climate change (Dutschke 2007).

This author has argued that some value should be attached to time. While proposals for the appropriate discount rate vary from $0 \%$ (e.g., Greenpeace International 2000, Kirschbaum 2006) to market rates of around 12\% per annum (e.g., van Kooten et al. 1997), a modest value (on the order of $1 \% /$ year), or its equivalent through alternative accounting mechanisms, would avoid distortions that militate against forests and against other societal interests at either the high or the low end of the range of possible discounts (Fearnside 2002b, c). If no value is given to time, future climate change, including glacial cycles that may be millenia in the future, eliminate any value of maintaining forest as a mitigation option. If the future is discounted very sharply, then the benefit of a reserve is also eliminated because the benefit would accrue after the value of the carbon has been discounted to a value near zero. Time preference represents an important difference between carbon and biodiversity considerations, and can result in different strategies being identified as priorities (Fearnside 1995c). The outcome of an ongoing theoretical battle over the value attached to time in carbon calculations is critical to any valuation of forest maintenance as a global-warming mitigation measure (Kirschbaum 2006, Fearnside 2008).

Permanence has been addressed by several proposals (including the ton-year accounting suggested by this author in 1992; see Fearnside et al. 2000), but the most politically tractable solution is the Colombian Proposal for temporary certified emissions reductions, or t-CERs (Blanco and Forner 2000). This is the approach adopted in the 2001 Marakesh Accords for afforestation and reforestation projects under the Clean Development Mechanism of the Kyoto Protocol (UN-FCCC 2001). Ways of accounting for "fractions of permanence" (Dutschke 2002) are needed in order to adjust mitigation decisions to the reality that no carbon is really permanent.

\section{Stocks versus flows}

The above discussion implies carbon accounting based on "additionality," or emissions reductions relative to a hypothetical (counterfactual) baseline representing what would have been emitted in a reference scenario without 
a mitigation action, such as creation of a forest reserve. This is the basis of accounting under the Kyoto Protocol's Clean Development Mechanism (UN-FCCC 1997, Article 12). Prior to the December 1997 Kyoto Protocol, this author proposed compensating environmental services of Amazonian forest based on stock maintenance, that is, with payments as an annual percentage of the stock value similar to the interest that is earned on a savings account in a bank (Fearnside 1997b). This form of accounting has recently re-emerged in discussion of how to market the carbon benefits of the "Amazonas Initiative" of the Amazonas state government. State governments in Brazil are becoming important actors in driving both diplomatic and technical advances towards making the environmental services of Amazonian forests into a force for environmental protection. These efforts complement federal initiatives such as that of the Ministry of the Environment's Protected Areas in Amazonia (ARPA) program. All of these initiatives require improvements in the knowledge base and in the human and physical resources needed for evaluating carbon stocks and properly accounting for and rewarding their maintenance.

The question of whether stocks or additionality (i.e., the basis of credit under the Kyoto Protocol's Clean Development Mechanism) should be the basis of accounting depends very much on the stage to which deforestation has advanced in an area. In locations where much has already been cleared (thereby providing a historical baseline) and rapid deforestation is underway, as in much of the state of Mato Grosso, the additionality criterion works well. In cases where very little has been cleared, as in the state of Amazonas, additionality will not work, at least not if calculated from a historical baseline. Additionality can be made to work in this situation with a simulated baseline based on planned road construction, or alternatively additionality can be replaced with stocks-based accounting. In cases where deforestation is well advanced and the rate is slowing for lack of available forest to clear, the historical baseline will no longer be appropriate (e.g., some parts of Mato Grosso: Fearnside 2003b). In places where the forest has almost all been cleared already, a historical baseline will produce "hot air," or credit with no climate benefit.

The choice between the two accounting methods has a strong influence on the social outcome. Under ad- ditionality the major beneficiaries are likely to be ranchers in Mato Grosso, whereas forest peoples in the state of Amazonas would be rewarded by the stocks-based approach. In either case, it is important that the baseline be based either on past history (i.e., on a period before carbon credit came under discussion) or on trends derived from past history. This is needed to avoid any possibility of stimulating clearing in order to raise the baseline and increase subsequent carbon credit. It is possible to have several systems simultaneously for forests in different situations.

\section{INSURING THAT BENEFITS ARE REAL}

Regardless of the accounting method, a basic priority is a system in which payments are only made for carbon benefits that are actually achieved, not for promises. It must be on a "pay-as-you-go" basis, not the "up-front" payments that project proponents inevitably want. For example, projects commonly call for planting a seedling and expect immediate credit for a full-grown tree. Guaranteeing that any carbon credit granted represents a real benefit for climate that has been accounted for in a fair, transparent and verifiable way is essential, and any deviation from this has a much greater potential environmental cost than the impact of any carbon emission that has been improperly permitted. The principal cost of such deviations is in jeopardizing the entire effort to develop an economy based on environmental services.

In the case of avoided deforestation, one must take the debit when deforestation increases along with the credit when it decreases. Otherwise the mitigation program has no more real benefit than speculating in the stock market, where the objective is to "buy low and sell high." Deforestation rates in Amazonia have risen and fallen with various macro-economic factors affecting availability of investment funds, commodity prices, exchange rates, inflation, land values, etc. (Fearnside 2005a). These oscillations have the potential to generate "hot air" carbon credit if only the decreases are counted.

Uncertainty is inherent in avoided-deforestation proposals, both with respect to the amount of emission avoided per hectare and the number of hectares avoided. Uncertainty is greater for avoided deforestation than for many other mitigation options, such as silvicultural plantations. Although progress has been made on reducing 
these uncertainties, much remains. In choosing between mitigation options and in assigning the credit to each, application of an overly demanding standard for uncertainty has substantial drawbacks because of a tradeoff between uncertainty and opportunity for climate benefits (Fearnside 2000c).

"Leakage" is one of the fears frequently raised with respect to avoided deforestation. Leakage refers to the carbon benefits from a mitigation project being wholly or partially nullified by emissions provoked by the project outside of its boundaries (including not only spatial boundaries, but also boundaries in terms of time and in terms of conceptual framework). For example, if a reserve is created, the people who would have been clearing forest in the reserve may simply move to another location in the region and clear just as much forest at the new location, thereby cancelling out the climatic benefit of the reserve. Most leakage is solved by accounting at the national level or at least at the level of very large political units, such as the state of Amazonas (1.5 million $\mathrm{km}^{2}$ ).

Unresolved issues need not be obstacles. Above all, it is a matter of attitude that determines if the existence of a problem is used as an excuse to reject proposals such as those to grant carbon credit for avoided deforestation, or whether the problem is viewed as just one more challenge to be faced and overcome. Our effort should go into solving the problems that can be identified and get on with the task of creating the institutional structures that are capable of turning the value of environmental services into monetary flows. These flows must be on the scale that is needed to change the course of history in Amazonia.

\section{CONCLUSIONS}

There is no time to lose in combating deforestation and in reducing impacts such as greenhouse-gas emissions. In the coming years critical thresholds are likely to be crossed in Amazonia, both in the deforestation process and in the forest's resistance to global warming. Waiting to take action makes the situation much worse because of delays in various parts of the system including the climate system (emissions-warming), the feedbacks that cause forest degeneration (global warming-savannization), and the impact of decisions (road building-deforestation).
All this points to the importance of acting now rather than waiting for climate impacts to become more apparent. Containing deforestation will require more than increased enforcement of environmental regulations: it will require giving value to forest maintenance by rewarding environmental services. Maintaining carbon stocks is the environmental service closest to becoming a basis for substantial monetary flows, although biodiversity and water cycling also have great importance and could generate additional flows over the long term. Rewarding carbon benefits requires appropriate accounting procedures for each phase of the deforestation process: the initial phase where little or no clearing has taken place, the phase of rapid clearing where plenty of forest remains available for clearing, and the declining phase where available forest is dwindling. Current negotiations focus on reducing carbon flows in the second of these phases, but additional arrangements are needed to reward carbon stocks for forests in the first phase, such as large areas in Brazil's state of Amazonas. For these largely intact areas, current decisions on highway construction and reserve creation are critical to the future fate of the forest.

\section{ACKNOWLEDGMENTS}

The Conselho Nacional do Desenvolvimento Científico e Tecnológico (CNPq: Proc. 306031/2004-3, 474548/ 2006-6, 557152/2005-4, 420199/2005-5), Rede GEOMA and the Instituto Nacional de Pesquisas da Amazônia (INPA: PPI PRJ05.57) contributed financial support. I am grateful for helpful reviewer comments.

\section{RESUMO}

A floresta amazônica produz serviços ambientais, tais como a manutenção da biodiversidade, da ciclagem de água e dos estoques de carbono. Estes serviços têm um valor muito maior para a sociedade humana do que a madeira, carne bovina e outros produtos que são obtidos destruindo a floresta. Mecanismos institucionais ainda estão faltando para transformar o valor da floresta em pé no alicerce de uma economia baseada em manter, em lugar de destruir, este ecossistema. Manejo florestal para madeira e para produtos florestais não-madeireiros enfrenta limitações severas e contradições inerentes a menos que a renda seja completada com base em serviços ambien- 
tais. A floresta amazônica é ameaçada por desmatamento, exploração madeireira, incêndios florestais e mudança climática. Medidas para evitar o desmatamento incluem repressão por comando e controle, criação de áreas protegidas, e reformulação de decisões sobre infra-estrutura e sobre políticas de desenvolvimento. Uma economia que é principalmente baseada no valor dos serviços ambientais é essencial para a manutenção a longo prazo da floresta. Muito progresso foi feito nas décadas desde que eu propus uma transição deste tipo, mas vários assuntos também permanecem não resolvidos. Estes incluem assuntos teóricos relativos aos procedimentos de contabilidade, quantificação melhorada dos serviços e dos benefícios de diferentes opções de política, e usos eficazes dos fundos gerados de modo que mantêm tanto a floresta como a população humana.

Palavras-chave: Amazônia, aquecimento global, carbono, desmatamento evitado, efeito estufa, floresta tropical.

\section{REFERENCES}

Alencar A, Solórzano L And Nepstad DC. 2004. Modeling forest understory fires in an eastern Amazonian landscape. Ecolog Applic 14: S139-S149.

Alencar A, Nepstad DC And Diaz VM del C. 2006. Forest understory fire in the Brazilian Amazon in ENSO and non-ENSO years: Area burned and committed carbon emissions. Earth Interact 10: 1-17.

ASNER GP, KNAPP DE, BroAdBent EN, Oliveira PJC, Keller M And Silva JN. 2005. Selective logging in the Brazilian Amazon. Science 310: 480-482.

Asner GP, Broadbent EN, Oliveira PJC, Keller M, KNAPP DE AND SILVA JNM. 2006. Condition and fate of logged forests in the Brazilian Amazon. Proc Nat Acad Sci 103: 12947-12950.

BARBOSA RI AND FEARnSIDE PM. 1999. Incêndios na Amazônia brasileira: Estimativa da emissão de gases do efeito estufa pela queima de diferentes ecossistemas de Roraima na passagem do evento "El Niño" (1997/98). Acta Amaz 29: 513-534.

Barlow J, Haugaasen T and Peres CA. 2002. Effects of ground fires on understory bird assemblages in Amazonian forests. Biol Conserv 105: 157-169.

Barreto P, Arima E AND Brito M. 2005. Cattle Ranching and Challenges for Environmental Conservation in the Amazon. IMAZON State of the Amazon No. 5, IMAZON, Belém, Pará, Brazil. 4 p. (Available at: http:// www.imazon.org.br).
Batjes NH And Sombroek WG. 1997. Possibilities for carbon sequestration in tropical and subtropical soils. Global Change Biol 3: 161-173.

Blanco JT And Forner C. 2000. Expiring CERs: A proposal to addressing the permanence issue for LUCF projects in the CDM. Economic and Financial Analysis Group, Ministry of the Environment, Bogotá, Colombia. FCCC/SB/2000/MISC.4/Add.2/Rev.1, 14 September 2000. (Available at: http://unfccc.int/125 resource/docs/ 2000/sbsta/misc08.pdf).

BRAZIL, ELETROBRAS. 1987. Plano 2010: Relatório Geral, Plano Nacional de Energia Elétrica 1987/2010 (Dezembro de 1987). Centrais Elétricas Brasileiras (ELETROBRAS), Rio de Janeiro, RJ, Brasil.

Brazil, MF, Secretaria dA Receita Federal. 2007. Perguntas e Respostas: Pessoa Juridica. Ministério da Fazenda (MF), Brasília, DF, Brasil, 812 p. (Available at: http://www.receita.fazenda.gov.br/Publico/Perguntao/ DIPJ2007/PergRespDIPJ2007.pdf).

BrazIL, MMA. 2003. Proambiente: Programa de Desenvolvimento Sustentável da produção Familiar Rural da Amazônia. Ministério do Meio Ambiente (MMA), Brasília, DF, Brasil.

Cochrane MA. 2003. Fire science for rainforests. Nature 421: 913-919.

Cochrane MA, Alencar A, Schulze MD, Souza Jr. CM, Nepstad DC, LEFEBVRE P ANd DAVIDSON EA. 1999. Positive feedbacks in the fire dynamic of closed canopy tropical forests. Science 284: 1832-1835.

CostanzA R ET AL. 1997. The value of the world's ecosystem services and natural capital. Nature 387: 253-260.

CostanzA R ET AL. 1998. The value of the World's ecosystem services and natural capital. Ecolog Econom 25: $3-15$.

Cox PM, Betts RA, Jones CD, Spall SA And TotTERDELL IJ. 2001. Acceleration of global warming due to carbon-cycle feedbacks in a coupled climate model. Nature 408: 184-187.

Cox PM, Betts RA, Collins M, Harris P, HuntingFORD C AND JONES CD. 2004. Amazonian dieback under climate-carbon cycle projections for the $21^{\text {st }}$ century. Theor Appl Climatol 78: 137-156.

DAILY GC ET AL. 2000. The value of nature and the nature of value. Science 289: 395-396.

D'Almeida C, Vörösmarty CJ, Hurtt GC, Marengo JA, Dingmanb SL And KeIme BD. 2007. The effects 
of deforestation on the hydrological cycle in Amazonia: A review on scale and resolution. Internat Jour Climatol 27: $633-647$.

De Jong BHJ, BazÁn EE and Montalvo SQ. 2004. Application of the Climafor baseline to determine leakage: The case of Scolel Té. Mitig Adapt Strat Global Change 12: 1153-1168.

DUTSCHKE M. 2002. Fractions of permanence: Squaring the cycle of sink carbon accounting. Mitig Adapt Strat Global Change 7: 381-402.

DUTSCHKE M. 2007. CDM forestry and the ultimate objective of the climate convention. Mitig Adapt Strat Global Change 12: 275-302.

FEARNSIDE PM. 1979. The development of the Amazon rain forest: Priority problems for the formulation of guidelines. Interciencia 4: 338-343.

FEARnside PM. 1985. Uma Estrutura para a Avaliação de Opções de Desenvolvimento Florestal na Amazônia. Presentation at the $1^{\circ}$ Seminário Internacional de Manejo em Floresta Tropical-SEMA/WWF, Serra dos Carajás, Pará, Brasil, 29 de janeiro.

FEARNSIDE PM. 1987. Causes of deforestation in the Brazilian Amazon. In: Dickinson RF (Ed), The Geophysiology of Amazonia: Vegetation and Climate Interactions. J Wiley \& Sons, New York, USA, p. 37-61.

FEARnside PM. 1989a. Forest management in Amazonia: The need for new criteria in evaluating development options. For Ecol Manage 27: 61-79.

FEARNSIDE PM. 1989b. Extractive reserves in Brazilian Amazonia: An opportunity to maintain tropical rain forest under sustainable use. Bio Sci 39: 387-393.

FEARNSIDE PM. 1989c. Brazil's Balbina Dam: Environment versus the legacy of the pharaohs in Amazonia. Environ Manage 13: 401-423.

FEARNSIDE PM. 1990. Reconsideração do cultivo contínuo na Amazônia. Rev Bras Biol 50: 833-840.

FEARNSIDE PM. 1995a. Hydroelectric dams in the Brazilian Amazon as sources of 'greenhouse' gases. Environ Conserv 22: 7-19.

FEARNSIDE PM. 1995b. Agroforestry in Brazil's Amazonian development policy: The role and limits of a potential use for degraded lands. In: CLÜSENER-GODT M AND SACHS I (Eds), Brazilian Perspectives on Sustainable Development of the Amazon Region. UNESCO, Paris, and Parthenon Publishing Group, Carnforth, U.K., p. $125-148$.
FEARNSIDE PM. 1995c. Global warming response options in Brazil's forest sector: Comparison of project-level costs and benefits. Biomass Bioenergy 8: 309-322.

FEARNSIDE PM. 1997a. Greenhouse gases from deforestation in Brazilian Amazonia: Net committed emissions. Clim Change 35: 321-360.

FEARNSIDE PM. 1997b. Environmental services as a strategy for sustainable development in rural Amazonia. Ecolog Econ 20: 53-70.

FEARNSIDE PM. 1999a. Biodiversity as an environmental service in Brazil's Amazonian forests: Risks, value and conservation. Environ Conserv 26: 305-321.

FEARNSIDE PM. 1999b. Forests and global warming mitigation in Brazil: Opportunities in the Brazilian forest sector for responses to global warming under the "Clean Development Mechanism.” Biomass Bioenergy 16: 171-189.

FEARnside PM. 1999c. Social impacts of Brazil's Tucuruí Dam. Environ Manage 24: 483-495.

FEARNSIDE PM. 2000a. Global warming and tropical landuse change: Greenhouse gas emissions from biomass burning, decomposition and soils in forest conversion, shifting cultivation and secondary vegetation. Clim Change 46: 115-158.

FEARNSIDE PM. 2000b. Greenhouse gas emissions from land-use change in Brazil's Amazon region. In: LAL R, Kimble JM and Stewart BA (Eds), Global Climate Change and Tropical Ecosystems. Advances in Soil Science. CRC Press, Boca Raton, Florida, USA, p. 231-249.

FEARNSIDE PM. 2000c. Uncertainty in land-use change and forestry sector mitigation options for global warming: Plantation silviculture versus avoided deforestation. Biomass Bioenergy 18: 457-468.

FEARNSIDE PM. 2001a. Saving tropical forests as a global warming countermeasure: An issue that divides the environmental movement. Ecolog Econ 39: 167-184.

FEARNSIDE PM. 2001b. Soybean cultivation as a threat to the environment in Brazil. Environ Conserv 28: 23-38.

FEARNSIDE PM. 2001c. Environmental impacts of Brazil's Tucuruí Dam: Unlearned lessons for hydroelectric development in Amazonia. Environ Manage 27: 377-396.

FEARnside PM. 2002a. Avança Brasil: Environmental and social consequences of Brazil's planned infrastructure in Amazonia. Environ Manage 30: 748-763.

FEARNSIDE PM. 2002b. Time preference in global warming calculations: A proposal for a unified index. Ecolog Econ 41: 21-31. 
FEARNSIDE PM. 2002c. Why a 100-year time horizon should be used for global warming mitigation calculations. Mitig Adapt Strat Global Change 7: 19-30.

FEARNSIDE PM. 2003a. Conservation policy in Brazilian Amazonia: Understanding the dilemmas. World Devel 31: $757-779$.

FEARNSIDE PM. 2003b. Deforestation control in Mato Grosso: A new model for slowing the loss of Brazil's Amazon forest. Ambio 32: 343-345.

Fearnside PM. 2004. A água de São Paulo e a floresta amazônica. Ciência Hoje 34(203): 63-65.

FEARNSIDE PM. 2005a. Deforestation in Brazilian Amazonia: History, rates and consequences. Conserv Biol 19: $680-688$

FEARNSIDE PM. 2005b. Brazil's Samuel Dam: Lessons for hydroelectric development policy and the environment in Amazonia. Environ Manage 35: 1-19.

FEARnside PM. 2006a. Mitigation of climatic change in the Amazon. In: LAURANCE WF AND Peres CA (Eds), Emerging Threats to Tropical Forests. University of Chicago Press, Chicago, Illinois, USA, p. 353-375.

FEARnside PM. 2006b. Dams in the Amazon: Belo Monte and Brazil's Hydroelectric Development of the Xingu River Basin. Environ Manage 38: 16-27.

FEARnside PM. 2007. Brazil's Cuiabá-Santarém (BR-163) Highway: The environmental cost of paving a soybean corridor through the Amazon. Environ Manage 39: 601614 .

FEARNSIDE PM. 2008. On the value of temporary carbon: A comment on Kirschbaum. Mitig Adapt Strat Global Change 13: 207-210.

FEARnside PM AND BARbosa RI. 1998. Soil carbon changes from conversion of forest to pasture in Brazilian Amazonia. For Ecol Manage 108: 147-166.

FEARnside PM AND BARbosa RI. 2003. Avoided deforestation in Amazonia as a global warming mitigation measure: The case of Mato Grosso. World Resour Rev 15: $352-361$.

FEARNSIDE PM AND FerRaZ J. 1995. A conservation gap analysis of Brazil's Amazonian vegetation. Conserv Biol 9: 1134-1147.

FEARNSIDE PM AND GRAÇA PMLA. 2006. BR-319: Brazil's Manaus-Porto Velho Highway and the potential impact of linking the arc of deforestation to central Amazonia. Environ Manage 38: 705-716.

Fearnside PM, Lashof DA and Moura-Costa P.
2000. Accounting for time in mitigating global warming through land-use change and forestry. Mitig Adapt Strat Global Change 5: 239-270.

Ferraro PJ AND Kiss A. 2002. Direct payments for biodiversity conservation. Science 298: 1718-1719.

Ferreira LV, Venticinque E AND DE Almeida SS. 2005. O Desmatamento na Amazônia e a importância das áreas protegidas. Estudos Avançados 19(53): 1-10.

FOLEY JA ET AL. 2007. Amazonia revealed: forest degradation and loss of ecosystem goods and services in the Amazon Basin. Frontiers Ecol Environ 5(1): 25-32.

Folha de SÃo PAUlo. 2007. "Banco quer financiar gado na Amazônia" 7 March 2007, p. A-14.

GreEnPEACE InTERnAtional. 2000. Should forests and other land use change activities be in the CDM? Greenpeace International, Amsterdam, the Netherlands. $24 \mathrm{p}$.

Grieg-Gran M, Porras I and Wunder S. 2005. How Can Market Mechanisms for Forest Environmental Services Help the Poor? Preliminary Lessons from Latin America. World Devel 33: 1511-1527.

Hecht SB, Norgaard RB and Possio C. 1988. The economics of cattle ranching in eastern Amazonia. Interciencia 13: 233-240.

Hegerl GC, Crowley TJ, Hyde WT and Frame DJ. 2006. Climate sensitivity constrained by temperature reconstructions over the past seven centuries. Nature 440: 1029-1032.

ipCC (Intergovernmental Panel on Climate Change). 2007. Summary for policymakers. In: SoloMON S, Qin D, MANning M, Chen Z, Marquis M, Averyt KB, Tignor M And Miller HL (Eds), Climate Change 2007: The Physical Science Basis. Contribution of Working Group I to the Fourth Assessment Report of the Intergovernmental Panel on Climate Change, Cambridge University Press, Cambridge, U.K., p. 1-18.

Karaousakis K. 2006. Initial Review of Policies and Incentives to Reduce GHG Emissions from Deforestation. COM/ENV/EPOC/IEA/SLT(2006)12. Organization for Economic Cooperation and Development (OECD), Paris, France. $19 \mathrm{p}$.

KARAOUSAKIS K. 2007. Incentives to reduce GHG emissions from deforestation: Lessons learned from Costa Rica and Mexico. Organization for Economic Co-operation and Development (OECD) and International Energy Agency (IEA), Paris, France. (Available at: http://www.oecd.org/env/cc/AIXG). 
KIRSCHBAUM MUF. 2006. Temporary carbon sequestration cannot prevent climate change. Mitig Adapt Strat Global Change 11: 1151-1164.

LAURANCE WF. 2006. Have we overstated the tropical biodiversity crisis? Trends Ecol Evol 22: 65-70.

Laurance WF, Cochrane MA, Bergen S, Fearnside PM, Delamônica P, BARber C, D'Angelo S AND FERNANDES T. 2001a. The future of the Brazilian Amazon. Science 291: 438-439.

Laurance WF, Albernaz A and Da Costa C. 2001 b. Is deforestation accelerating in the Brazilian Amazon? Environ Conserv 28: 305-311.

Mattos L, Faleiro A And Pereira C. 2001. Uma proposta alternativa para o desenvolvimento da agricultura familiar rural na Amazônia: O caso do PROAMBIENTE. IV Encontro Nacional da Sociedade Internacional de Economia Ecológica-ECO-ECO, NEPAM, Universidade Estadual de Campinas (UNICAMP), Campinas, SP, Brasil. (www.nepam.unicamp.br/ecoeco/artigos/encontros/ encontro4_plenaria.html).

MoOney HA AND Ehrlich PR. 1997. Ecosystem services: A fragmentary history. In: DAILY GC (Ed). Nature's Services: Societal Dependence on Natural Ecosystems. Island Press, Covelo, California. USA, p. 11-19.

NePstAD DC ET AL. 1999. Large-scale impoverishment of Amazonian forests by logging and fire. Nature 398: 505-508.

Nepstad DC, Carvalho G, Barros AC, Alencar A, Capobianco JP, Bishop J, Moutinho P, LefebVRe P, Silva JR. UL AND PRins E. 2001. Road paving, fire regime feedbacks, and the future of Amazon forests. For Ecol Manage 154: 395-407.

NEPSTAD DC ET AL. 2006. Inhibition of Amazon deforestation and fire by parks and indigenous reserves. Conserv Biol 20: 65-73.

Pimentel D, Wilson C, McCullum C, Huang R, Dwen P, Flack J, Tran Q, Saltman T and ClifF B. 1997. Economic and environmental benefits of biodiversity. Bio Sci 47: 747-757.

Salazar LF, Nobre CA And Oyama MD. 2007. Climate change consequences on the biome distribution in tropical South America. Geophys Res Lett 34: L09708 doi:10.1029/2007GL029695.

Sampaio G, Nobre C, Costa MH, Satyamurty P, SoARES-FILHo BS AND CARdoso M. 2007. Regional climate change over eastern Amazonia caused by pasture and soybean cropland expansion. Geophys Res Lett
34: L17709, doi:10.1029/2007GL030612.

SÁNChez PA, BANdy DE, VILlachica JH AND NiCHOLAIDES III JJ. 1982. Amazon basin soils: Management for continuous crop production. Science 216: $821-827$

SLOAN S. 2007. Fewer people may not mean more forest for Latin American forest frontiers. Biotropica 39(4): 443-446.

Smith N, Dubois J, Current D, Lutz E and Clement C. 1998. Agroforestry Experiences in the Brazilian Amazon: Constraints and Opportunities. Pilot Program to Conserve the Brazilian Rain Forest, Brasília, DF, Brazil. 67 p.

Soares-Filho BS, Alencar A, Nepstad D, CerqueiRA G, Diaz M Del CV, Rivero S, Solórzano L AND Voll E. 2004. Simulating the response of landcover changes to road paving and governance along a major Amazon highway: The Santarém-Cuiabá corridor. Global Change Biol 10: 745-764.

Soares-Filho BS, Nepstad DC, Curran LM, CerQueira GC, Garcia RA, Ramos CA, Voll E, McDonald A, Lefebvre P AND Schlesinger P. 2006. Modelling conservation in the Amazon Basin. Nature 440: 520-523.

Souza Jr C, Veríssimo A, Micol L, Guimarães S, Brandão JR. A, Costa A, SAlomão R, dos SANTOS RR AND ABAD R. 2007. Transparência Florestal: Estado de Mato Grosso. Instituto do Homem e Meio Ambiente da Amazônia (IMAZON), Belém, Pará, Brasil. 8 p. (Available at: http://www.imazon.org.br/publicacoes/ publicacao.asp?id=514).

STAINFORTH DA ET AL. 2005. Uncertainty in predictions of the climate response to rising levels of greenhouse gases. Nature 433: 403-406.

TipPeR R AND De JONG BH. 1998. Quantification and regulation of carbon offsets from forestry: comparison of alternative methodologies, with special reference to Chiapas, Mexico. Commonweal For Rev 77: 219-227.

Uhl C AND BuschBacher R. 1985. A disturbing synergism between cattle-ranch burning practices and selective tree harvesting in the eastern Amazon. Biotropica 17: 265-268.

UN-FCCC (United Nations Framework CONVENtion on Climate Change). 1997. Kyoto Protocol to the United Nations Framework Convention on Climate Change, Document FCCC/CP/1997;7/Add1 (available in English at: http://www.unfccc.de and in Portuguese at: http://www.mct.gov.br/clima). 
UN-FCCC (United Nations Framework CONVENtion on Climate Change). 2001. Decision 17/CP.7: Modalities and Procedures for a Clean Development Mechanism as Defined in Article 12 of the Kyoto Protocol. Marrakech, 28 October to 9 November. (http://www.unfccc.int/)

VAn Kooten GC, Grainger A, Ley E, Marland G AND Solberg B. 1997. Conceptual issues related to carbon sequestration: Uncertainty and time. Crit Rev Environ Sci Technol 7(special): S65-S82.

Viana V and CAmpos MT. 2007. Bolsa Floresta: Recompensa para Quem Conserva a Floresta em Pé. Secretaria do Estado do Meio Ambiente e Desenvolvimento Sustentável (SDS), Manaus, Amazonas, Brazil. 13 p.
Wright SJ AND Muller-Landau HC. 2006. The future of tropical species. Biotropica 38: 287-301.

Zarin DJ, Alavalapati JRR, Putz FE and Schmink M (EDS). 2004. Working Forests in the Neotropics: Conservation through Sustainable Management? Columbia University Press, New York, USA, 437 p.

ZBINDEN S AND LEE DR. 2005. Paying for environmental services: An analysis of participation in Costa Rica's PSA program. World Devel 33: 255-272. 